\title{
The End of Academic Freedom in the Era of Neoliberalism? ${ }^{1}$
}

\author{
Kateřina Lojdová \\ Masaryk University, Faculty of Education, Department of Education \\ Received $27^{\text {th }}$ September 2016 / final version received $13^{\text {th }}$ February 2017 / \\ accepted $15^{\text {th }}$ February 2017
}

\begin{abstract}
This paper considers the potential consequences of neoliberalism for present-day universities. From the perspective of critical pedagogy, it focuses on the possible conflicts between neoliberalism and academic freedom as the fundamental component of the academic spirit at universities. The article consists of two parts. The first part introduces critical pedagogy, its roots and its current form, including the limitations that this concept has. The second part then discusses the neoliberal transformation of research and teaching at universities from the critical-pedagogical perspective, as shown in the example of pedagogical faculties. The conclusion outlines possibilities of critical pedagogy to cultivate an academic spirit at universities. It finds them, for example, in research independent from grant schemes, but nonetheless relevant to the professional community, in the sensitive management of universities and in undergraduate teaching curricula that accentuates the broadminded teacher rather than competency-based education. The article ends with a conciliatory vision of sustainable academic life that balances on the border between the economic dimension of universities and academic freedom independent of the labor market.
\end{abstract}

Keywords: academic freedom, competency-based education, critical pedagogy, critical theory, neoliberalism, undergraduate teacher education, tertiary education

Our faculty management recently started keeping track of work attendance. This was an understandable move corresponding with the labor code, yet the measure was received by some of the faculty with a degree of discomfort. While working during designated working hours is common practice in most professions, it is almost impossible in an academic environment. Indeed, teaching and some research activities can (with a bit of luck) be managed during working hours. However, the real research and development of the

1 This study is part of the research project Classroom Management Strategies of Student Teachers and Experienced Teachers (Their Mentors) in Lower Secondary Education (GA1602177S) granted by the Czech Science Foundation. 
discipline such as writing reviews simply do not fit within the working hours. Many leave the luxury of reading, writing, and in particular thinking, for evenings and weekends. But with this step, the core of academic work then officially moves from the legitimately defined working hours into a kind of illegality.

The above-mentioned step can be put into the context of late modernity and neoliberalism in education. In terms of late modernity, it can represent a clash of the old working orders with the new situation of late modern working conditions. There is also an affinity between late modernity and neoliberalism. Neoliberalism fits with the increasingly individualized and uncertain conditions of late modernity (Dawson, 2013). We will focus on neoliberalism because of the strong educational discourse surrounding this term. Although using the term neoliberal in the context of Czech faculties of education might seem an exaggeration, it is noticeable that some elements of neoliberalism are slowly and quietly emerging. This text attempts to contemplate what neoliberalism can bring to two crucial areas of academic life - research and teaching. It is in these areas that academic spirit and academic freedom are cultivated, and with which neoliberal policies do not much resonate.

Criticizing neoliberalism in education is an integral part of critical pedagogy. However, it should be noted that among the critics of neoliberalism are particularly those who are not responsible for university management. This is also the position of the author of this text, which is important to mention at the very beginning, as it is the position of someone who is not responsible for securing funding for academic life at the faculty. From this perspective, the text might appear one-sided. This text is based on critical pedagogy that will be introduced in the first chapter. This chapter concerns critical pedagogy. The second chapter presents the critical-pedagogical perspective on the transformation of the university environment during the era referred to as neoliberalism.

\section{Context of critical pedagogy}

Critical pedagogy is a relatively recent concept. It was used for the first time in a printed text in 1983 by Henry Giroux in his Theory and Resistance in Education (Darder, Baltodano, \& Torres, 2003, p. 2). In this work, Giroux 
acknowledges the legacy of the Frankfurt School ${ }^{2}$ and hence brings critical theory into pedagogy. Of course, critical theory in pedagogy had already been developed by Giroux's predecessors, although they did not use the term critical pedagogy. Many consider John Dewey as the author who opened the door for critical pedagogy. He is referred to as the father of the progressive educational movement. His pragmatic pedagogy stresses the importance of education in a democratic society. His work, which contributes to the discourse of democracy and freedom, makes John Dewey the most significant thinker to enable the emergence of critical pedagogy (Darder, Baltodano, \& Torres, 2003).

Another starting point for critical pedagogy is the pedagogy of the oppressed by Paulo Freire. Some authors agree that critical pedagogy gained significance due to Freire's publication Pedagogy of the Oppressed from 1970 (Smith \& McLaren, 2010). According to Freire, education became an act of storage wherein students are viewed as a storehouse of knowledge and teachers as the depositors of knowledge. "Instead of mutual communication with students, the teacher deposits topics that the students receive, remember and repeat" (Freire, 2000, p. 72). Freire calls such education banking education, where the teacher deposits information into pupils as into a bank. This kind of education fails to teach students (and this also applies to adults whose education Freire addressed) to consider reality critically (Freire, 2000). The central point of Freire's criticism of education is the lack of critical thinking in students and resignation from its development during the educational process. With his work Deschooling Society from the early 1970s, the Austrian Ivan Illich could also be referred to as a critical-pedagogical thinker. This work resonates with the criticism of the power of institutions (compare Foucault, 1975), in this case the school, the importance of which is relativized: "Most of what we know, we've learned outside of school" (Illich, 2001, p. 34). Since the late 1970s, influential studies have been conducted in the USA by Michael Apple who is seeking to explore the structures and relationship in education, economy, government, and culture that both control us and enable fruitful, more democratic activity (Apple, 2013).

2 The term Frankfurt School refers to various streams of philosophical thinking, based on the work of the Frankfurt School thinkers founded in 1923 in Frankfurt. These thinkers developed critical theory. According to Horkheimer, critical theory should systematically critique existing society and seek to create an alternative to capitalism and fascism (Harrington, 2006). 
Thinking by critical pedagogues was affected by sociological theories, mainly reproduction theories that examine social hierarchy reproduction, cultural reproduction, resistance and social identity. Critical pedagogues found inspiration in the concepts of cultural and symbolic capital, through which Bourdieu demonstrates how power is manifested and reproduced in society (Darity, 2008). All forms of capital serve the individual to gain certain social positions and positions of power, and hence are relevant to critical pedagogy (cf. Cho, 2010).

Besides the aforementioned Henry Giroux, among the most significant authors of critical pedagogy are in alphabetical order Seehwa Cho, Antonia Darder, Elisabeth Ellsworth, Barry Kanpol, Joe L. Kincheloe, Donald Macedo, Peter McLaren, Jennifer Sandlin, Shirley Steinberg, Ira Shor.

\subsection{The bogey of neoliberalism}

The center of critical pedagogy is the relationship between knowledge and power during the present time, referred to by critical pedagogues as the era of neoliberalism ${ }^{3}$. Neoliberalism is a specific economic discourse, which according to some authors, has become the dominant form of economic relationships in the world. It is typical for the interconnection of the political and the economic (Kaščák \& Pupala, 2011). Entrenching neoliberalism can be connected with the failure of the critical movement in the 1960s featuring a "doctrine with a clear vision of the organization of a society that should be based solely and unquestionably on the market principle and property rights with the clearly stated means of achieving this organization" (Lupták, 2013, p. 11). From an international perspective, it is primarily the American environment that represents neoliberal policies. The era of neoliberalism is regarded (Giroux 2012a) as the period of the past 40 years where American society has been based on market fundamentalism, consumerism and the promotion of individual interests rather than democratic rights and social responsibility. The American author Apple (2012, p. 6) even characterizes neoliberalism as a "religion because neoliberalism - a vision that sees every sector of society as subject to the logics of commodification, marketization, competition and cost-benefit analysis - seems to be immune to empirical arguments, especially but not only in education".

3 Neoliberalism in this context is mainly defined by critical pedagogues that is by those critical of this concept. In pedagogy, neoliberalism is mentioned mostly from the critical perspective, which means that a specific discourse of neoliberalism was created within pedagogy. 
Neoliberalism is reflected in educational practice (in educational institutions) as well as in educational theories (in educational concepts). The neoliberal transformation of educational practice at universities is addressed in Chapter 2. This is where an example is given of one current concept in the field of education which, according to some authors, points to neoliberalism in education. The Austrian philosopher Liessmann (2008, p. 28) illustrates the criticism of neoliberalism on the concept of competencies. Liessmann says that there is diversion from the idea of education visible in educational goals. According to the author, an obvious indicator of this can be found in skills and competencies as educational goals.

While in German-speaking countries, critics of neoliberalism mainly address the topic of the curriculum (cf. Liessmann, 2008), in English-speaking countries the wider social implications of neoliberalism are at the center of attention (cf. Giroux, 2004). Giroux (2012b) criticizes neoliberalism as a system of reproducing inequality, since it does not include moral responsibility, but instead focuses only on material benefits and power. Giroux is not afraid to use revolutionary titles for his text, such as The Terror of Neoliberalism: Authoritarianism and the Eclipse of Democracy (2004) or Neoliberal Terror and the Age of Disposability (2012b). The diction of other critical pedagogues is also very radical. ${ }^{4}$

According to critical pedagogues, it is the era of neoliberalism that requires reflective tools for analyzing the relationships of power and the subordinate cultural and social position. According to some authors, critical pedagogy could be such a tool that could not only disrupt this system, but also create new public spheres based on the principles of equality, freedom and justice. According to Giroux, students need to understand the social construction from different perspectives and identities and understand how these were constructed culturally and historically. Incorporating various constructs of reality into the curriculum and their reflection by the students is, according to critical pedagogues, a part of democratic society (Collins, 2008). Giroux's concept of critical pedagogy is characterized by the demand for radical democratization of the society. He stresses the necessity of a political, social

4 For example, S. Steinberg says in the introduction of her Critical Pedagogy: Where Are We Now (2007): "Critical pedagogy has the right to be angry, and to express anger, anger at abuses of power and injustices through the violations of human rights. Critical pedagogy isn't a talk - liberal talk. Critical pedagogy takes language from the radical - radicals must do." (Steinberg, 2007, p. 9) 
and ethical turn in the view of citizenship. According to the author, the commitment of all members of the society is desirable in the newly created global public space (Giroux, 2001, p. 30).

Critical pedagogues believe that the tool for removing social inequalities in society is knowledge. It is knowledge that empowers, hence it is a tool of power. Cho (2010) claims that the most significant goal of critical pedagogy is uncovering the relationship between knowledge and power. This relationship is critically examined especially from the perspectives of class, race and gender. The result of this process is critical pedagogy aimed at constructing counter-hegemonic ${ }^{5}$ forms of knowledge, which is those that differ from dominant ideologies.

\subsection{The myth of apolitical pedagogy}

According to Giroux (2013), pedagogy is associated with transferring a certain agenda and, therefore, it is always political in nature. Critical pedagogy views each dimension of education as political (Kincheloe, 2004b) since the curriculum contains elements of the dominant ideology. Critical pedagogues interpret mainly the hidden curriculum as a powerful tool of student indoctrination through routines and unvoiced norms in the school's everyday life. According to Giroux, it is necessary that the teacher knows how to question knowledge in education and shed light on the hidden curriculum (Bertrand, 1998). The critical pedagogical concept of a hidden curriculum was contributed to in particular by two of McLaren's publications: Schooling as ritual performance (1999) and Life in schools (1998). McLaren regards the hidden curriculum as a tacit way in which students acquire knowledge and learn behavior patterns that are in accordance with dominant ideologies and cultural practices. Aronowitz and Giroux (2003) also approach the hidden curriculum as a means by which the dominant capitalist ideology shapes the school experience and contributes to labor force reproduction, often "behind the backs" of pupils and teachers. Critical pedagogue Kincheloe (2004b, p. 3) adds radically that the value reproduction in the school supports the dominant status quo rather than the pupils' needs.

Some authors go even further than Giroux and treat critical pedagogy as a revolutionary political tool. For example, McLaren unveils supranational capitalism as a force shaping the educational policy, inequality and

5 An analysis of hegemony in education is pursued, among others, by Apple (2004). 
oppression (Farahmandpur, 2005). The revolutionary critical pedagogy is then formulated as a counter position to capitalism. The revolutionary critical pedagogy is based on Marx's historical materialism and class struggle. McLaren and, for example, Giroux therefore bring the neo-Marxist position into critical pedagogy (Cho, 2012). The aim of McLaren's revolutionary critical pedagogy is to prepare critical educators, who will also be revolutionary agents in the fight against capitalism (Farahmandpur, 2005). From a political perspective, the key role of teachers therefore emerges. The teacher is conceived as a critical intellectual (Collins, 2008) and a political agent, who, according to these theories, should strive to reorganize the power structure within the society.

\subsection{Idealism, utopia and the vagueness of critical pedagogy}

Critical pedagogy is, of course, a target of much criticism for being idealistic, utopian and overly influenced by Marxism (Guthrie, 2003). The revolutionary undertones of critical pedagogy and its political radicalism might make it controversial for staking a claim for a patent on an ideal social arrangement. Critical pedagogues pointed out that school is an environment where social inequality is reproduced. It seems, however, that critical pedagogy is also unable to remove inequalities, and as an "equalizer" of social inequalities, it fails just like the institution of school. As for the past thirty plus years of its development, it has not significantly affected the transformation of society. Moreover, it seems that critical pedagogues forgot or overlooked the role of the school in the removal of social inequalities. And they would not have even needed to venture too far into the past, since during Paulo Freire's time compulsory school attendance made it possible to significantly reduce the number of illiterate people in the population. Particularly in developing countries, equal access to education is nowadays still a pressing topic. In so-called developed countries, equality in relation to the type of school is being discussed. In this case, the school might as well equalize differences between pupils. The greatest potential for this type of equalizing of uneven opportunities lies in pre-school education (Greger, Simonová, \& Straková, 2015).

It seems that the criticism of the school as an environment reproducing inequality is some sort of fashion trend, while the authors do not consider the other side of the coin, which is that the school can also erase social inequalities. Critical pedagogy seeks to eliminate inequalities in society 
although it should be noted that attempts to eliminate social inequalities lead only to the creation of other forms of inequality (Keller, 2012), which is not usually reflected by critical pedagogues.

Another issue of critical pedagogy is its inconsistent concept: "In the last fifteen years, critical pedagogues have debated what it means to be critical and how this concept can be incorporated into the curriculum" (Semali, 1998, p. 137). Authors, therefore, do not contribute to the consistency of the concept of critical pedagogy. Rather, they construct it as a postmodern discourse full of diversities. Their gaze is often turned to the future rather than to the present time. They formulate what critical pedagogy should be and what issues it should address (cf. Kincheloe, 2007). So what is critical pedagogy good for?

\subsection{So what is critical pedagogy good for?}

Critical pedagogy can contribute to a wider debate on education and to the debate on alternative ways to build a better world. Its potential for this is its reflective character and problem-based approach (Orelus, 2011). Critical pedagogy directs our attention to the micro-social and macro-social context of education. In the micro-social context, it offers a reflection of students' position in the education system hierarchy in connection with their racial, class or gender characteristics. In the macro-social perspective, it highlights the relationships of education and sociopolitical situations. It addresses the potential dangers of school transformation under neoliberal politics.

Specifically, critical pedagogy can take the form of learning conductive of critical thinking (Breunig, 2005). Critical thinking is emphasized as a necessity for participating in a democratic community (Kincheloe, 2007), which might be school, as well as society. Critical pedagogy does not need to be directed towards a radical transformation of society, which is preached by critical pedagogues, but might be projected into school culture and influence it so that it becomes more emancipatory and democratic. The effect of such a school may also be the transformation of the society, even if less radical and much slower.

Therefore, critical pedagogy as an intellectual movement might have its place at universities for several reasons: 1) It takes into account the macro-social context in education and calls for its analysis. 2) It creates provocative views that may not be consistent with the status quo of the education policy. 3) It leads students and teachers into intervening into educational reality. 
Critical pedagogy can thus encourage the academic spirit in tertiary education. Its critical application suggests itself particularly at faculties of education. The next chapter will address the critical-pedagogical position to the neoliberal transformation of universities.

\section{Neoliberal universities}

If we were to point one specific defining political/economic paradigm of the age we live, it would be neoliberalism (Apple, 2006, s. 14). Neoliberalism has risen not because of its intellectual power or popular appeal, but because of its utility to individuals and corporations (Horn, 1999). Universities were not left aside and some elements of neoliberal policies can be gradually projected into them, causing a significant transformation (where it is necessary to distinguish the American, British, German and Czech context) ${ }^{6}$. Hence, some authors talk about neoliberal universities:

A neoliberal university is defined as a self-interested, entrepreneurial organization offering recursive educational experiences and research services for paying clients. In such institutions academics become managed knowledge producers who should follow prescribed sets of organizational processes. Their research and pedagogic must be justified as beneficial for university through quantitate measures. Students are recast in the role of knowledge consumers, and have a voice in determining the manner in which educational services are packaged and delivered to them. (Hadley, 2015, s. 6)

6 This process of change has been witnessed in USA and UK approximately 30 plus years ago. In the USA a time when national funding for higher education began to shrink due to a combination of declining tax base and conservative shifts in attitudes of part of policy makers (Hadley, 2015). In the UK and other western advanced economies, the nature of government, civil society and democracy has been changing over the last 30 years. According to Harris (2005) the social democratic state of the post-war era has been replaced by a neoliberal consumer democracy in which democracy has come to be defined in economic rather than political terms. Of central concern to governments is the need to strengthen the economy and economic competitiveness in order to compete in international and global markets. In Germany the liberal camp wanted to modernize the German university by emphasizing the needs of the labor market and emphasized strong critique of the Humboldt model (Hohendahl, 2011). Debates about neoliberalism in the Czech educational discourse are stated similarly by Štech (2007), while he also adds that these elements enter the educational policies later, pre-prepared by this discourse. Compared to the American context, neoliberalism emerges at Czech universities later and with lesser intensity. 
Hadley (2015) adds that while often accepted in many countries as a reasonable to govern and run profit-driven corporations, a significant amount of research has studied how a new managerial caste, guided by neoliberal beliefs of governance, has transformed organizational culture and professional practices of schools and universities. Giroux (2015a) states that this transformation of the university is characterized by an organizational culture so that the traditional academic imperative "publish or we perish" is now supplemented with the neoliberal mantra "privatize or we perish", as everyone in the university is transformed into an entrepreneur, customer, or client and every relationship is ultimately judged in cost-effective terms. Liessmann's thoughts (2008) also comment on the concept of the neoliberal university in a very critical tone: "The tragedy, which occurred under the pressure of ideologization and politicization of universities in the last century, is currently repeating itself under the baton of economization, but as a farce". Liessmann criticizes these trends in the education system, from the primary to the tertiary.

However, in the context of these rebukes, it should be noted that public universities are public services characterized by employees paid from public funding. As such, universities have a social responsibility, which relates, inter alia, to their contribution to economic growth (Pavlík \& Bělč́k, et al., 2010). Thinking of universities in relation to cost-effectiveness seems completely legitimate in this context. But unlike a factory, the university is a specific kind of institution since many of its outcomes cannot be measured in economic terms or "sold" (for example, basic research outcomes), or the outcomes only turn out to be significant or insignificant many years later. The existence of universities has always been legitimized by public welfare which is, however, hard to define, and today can also be framed by neoliberalism.

Rejecting neoliberalism by academics can be for very utilitarian reasons. One of the reasons is power relations. Bourdieu (1988, p. 40) mentions that "the structure of university field reflects the structure of the field of power, while its own activity of selection and indoctrination contributes to reproduction of that structure". Academics might also criticize neoliberalism at universities for the reason that it undermines their power and the traditional power structures at the university. Last, but not least, criticizing neoliberalism might conceal a reluctance or inability of academics to conduct challenging research. 
Regardless of these utilitarian interests of academics, we can consider a certain kind of anomie that neoliberalism might cause at universities. The neoliberal conception of the university particularly conflicts with the traditional Humboldtian ideal of university. In the last two hundred years or so, universities have been perceived in the Humboldtian spirit as "places of discovery and passing on new knowledge thanks to the joint activities of professors and students, in the independent search for truth and free development of teaching and research" (Šima \& Pabian, 2013, s. 11). Although Humboldt's influence on current universities is sometimes considered overrated and Humboldtian university in practice is considered by these authors to be a myth (Šima \& Pabian, 2013), the idea of the academic spirit expressed in this quote is still one of the main characteristics of universities.

Academic spirit is fairly difficult to define. One of the reasons for this is the fact that academic work is relatively non-codified. Kennedy (1997) comments that universities are, in this sense, societies without rules. Therefore, although academic spirit is often mentioned in everyday language, papers and studies usually prefer to talk about academic freedom. Academic freedom is understood in this paper to be the core of the academic spirit.

A narrow definition of academic freedom limits it to the freedom of professors to teach their subject, carry out research, and publish its results subject to professionally sanctioned limits. Over the years, academic freedom has come to include the freedom to participate in public life, and perhaps still controversially to criticize the institution in which professors work. (Horn, 1999, p. 10)

It is this space for disagreement and controversy that constitute a part of academic freedom, as already pointed out by Capene in 1948 (in Aby \& Kuhn, 2000). Hence, academics can, among other things, criticize the practices of the institution that sustains them. According to Kennedy (1997), we feel that the term academic freedom has always been present, but in fact it only emerged at the beginning of the 20th century.

Academic freedom can be divided into two levels - individual and institutional (Malcolm in Aby \& Kuhn, 2000). In the context of neoliberalism, the institutional level is mostly discussed. The addressed topics are managerialism at universities (Kolsaker, 2008; Peters, 2013), audit culture and the related accountability (Strathern, 2000; Dill, 1999), marketization of education and research (Harris, 2005; Lynch, 2006), commodification of academic practice (Ball, 2012), accreditation, international competitiveness, and privatization (Torres, 2008). 
Neoliberalism is the agent that connects the criterion of measurability, effectivity and quantity into the university environment. Ball (2012,p.19) calls this the performativity mode that, according to him, can be found at all levels of education: "In regimes of performativity experience is nothing, productivity is everything. Last year's efforts are a benchmark for improvement - more publications, more research grants, more students". Mountz et al. (2015, p. 1237) speaks about "the acceleration of time in which we are expected to do more and more. The 'more' includes major tasks, such as teaching larger classes, competing for dwindling publicly funded grants that also bring operating money to our universities, or sitting on innumerable university administrative committees".

This perfomativity can be seen in two core ingredients of the academic work - in research (scientific and scholarly work) and in teaching (university curriculum). The area of research is, according to many authors, superordinate to teaching (cf. Barnett, 2003; Šima \& Pabian, 2013). Nevertheless, academic freedom is perceived to be the essence of both these areas. Hence, we should consider the transformation of the research and university curriculum under the influence of neoliberalism.

\subsection{Academic spirit in the neoliberal research}

According to many authors, academic freedom is the essence of academic work:

Academic freedom consists of nothing more than the conditions necessary to follow the established criteria for scholarship and teaching within each discipline. Faculty members should be largely free in pursuing their scholarship and teaching subject only to evaluation on academic grounds and primarily by peers. (Fish, 2014, p. 54)

Good scholarship requires time: to think, write, read, research, analyze, edit, organize, and resist the growing administrative and professional demands that disrupt these crucial processes of intellectual growth and personal freedom (Mountz et al., 2015). Time is, however, the enemy of neoliberalism. Cultivating the academic spirit is slow and in the economic sense inefficient and the results of these efforts might not be directly usable in practice. Economic pressures may lead to weakening of the academic spirit. 
Hatcher, Meadmore, and McWilliam (1999, p. 69) argued that "one sort of romance about being an academic is no longer speakable, thinkable, doable in universities at the turn of the millennium, and we have tracked the end of that romance to a different discursive organisation of university management in the 1990s". Authors noted the influence of organisational theory emanating from non-traditional sources and described presence of a new discursive tradition in universities, one that is giving birth to a new romance in which the enterprising academic is a central figure. In the context of this transformation of academic identity, Ball (2012, p. 9) recalls Weber's concept of specialists without spirit ${ }^{7}$.

Bränström Öhman (2012, p. 28) is also dedicated to this transformation of academic work and calls it a utilitarian turn connected to the neoliberalization of the Western university. She also argues that it represents the shift from content to counting. Writing becomes an instrumental skill rather than an epistemological experience: in the pressure to count, we become guided by "the ever-deceptive promise of one size fits all" (Bränström Öhman, 2012, p. 29). It is academic writing that is the breeding ground for the academic spirit. It is the privilege of universities. Through academic writing, knowledge is created and reproduced and individual subjects are developed. However, traditional academic writing does not need to match the reporting system of science and research. In the Czech Republic, emphasis is particularly placed on publication outputs that contain original research investigation. On the one hand, it is understandable that the methodology of evaluating the results of research organizations attempts to develop its own empirical research in individual scientific disciplines. At the same time, however, it cannot be claimed that outputs of different types are not significant for science. It is a question of how the current methodology would evaluate publications such as Freire's Pedagogy of the Oppressed or Illich's Deschooling Society. These works are neither of a research nature nor overview studies. Although when evaluating publications and taking the quality into account, academic writing is becoming a kind of craft more than a kind of art. In this system, it is possible to publish "mechanical texts" that formally meet the methodological criteria but do not contribute to developing scientific discipline. The

Weber's distaste for the celebration of the mundane and the routine central to modern culture is expressed by the "iron cage" imagery. He adds, however, a quotation from Goethe: "Specialists without spirit, sensualists without heart; this nullity imagines that it has attained a level of civilisation never before achieved" (Giddens in Weber, 2002). 
increasing quantity of texts also contributes to fragmented knowledge. It is difficult to orientate in the large amount of text and it can easily happen that a scholar conducts research without being informed of current publications. Besides, the publication strategy focused on collecting points marginalizes certain kinds of texts. For example, writing discussion contributions or publication reviews is not economically profitable for university employees. These texts therefore recede into the background, although they are crucially important - they comment on and link knowledge and hence shape the scientific discipline culture. Simply put, there is not time to read colleagues' texts, let alone react to them. Academic freedom is also restricted for the simple reason that academics cannot afford to write such texts.

This transformation of academic writing was soon answered by predatory journals that make it possible to fulfill criteria for scientific publications without regard to the quality, and without any need for peer-review, but rather for money. This policy then enabled a peculiar publication business to develop. Phenomenon of predatory journals was illustrated in 2016 by Czech academics using the pseudonyms Jan Babinský and Václav Krejčír, who published the article Representation of Ukrainian Crisis in Czech Media: Explicit and Implicit Bias in the News Coverage of the Ukranian-Russian Conflict in Mediterranean Journal of Social Sciences. ${ }^{8}$. They inserted the following paragraph into the article where they explicitly state that the article is entirely fabricated. Despite this, the paper was published:

This article was produced as an experiment intended to verify suspected unethical publishing practices of so-called predatory or junk journals. The article is purposefully flawed both methodologically and conceptually, and written in poor English. The reason why we took this action is that the articles published in this journal are often presented as distinguished academic publications although the journal does not guarantee standard peer-review process and elementary editorial service. The articles are neither supervised for academic accuracy and relevance nor checked for the quality of language and style. All of these statements are proven true by the very fact that you are able to read them (p. 439).

In relation to scholarly and scientific work, we refer to the culture of output (in the Czech context, the metaphor of a coffee grinder is often used ${ }^{9}$ ),

http://www.mcser.org/journal/index.php/mjss/article/view/9339/9019.

9 The essence of the "coffee grinder" is the directly proportional relationship between the evaluation of the result (given points) and funds for public support that the workplace receives (http://metodikahodnoceni.blogspot.cz/2014/12/dobry-zly-kafemlejnek-ii.html). 
which might lead to authorship misconduct ${ }^{10}$ on the side of the authors and expansion of predatory journals ${ }^{11}$ on the side of the editors. These are the phenomena that cater to the neoliberal criteria of effectivity but move away from the academic spirit. Many universities then support academic freedom rhetorically, but not institutionally. On the institutional level, they strive for "countable" scientific outputs, as these generate financial funding. Publications are no longer written, they are "produced". Capen (in Aby \& Kuhn, 2000) however argues that universities must support academic freedom even if it costs them money. This is where the academic spirit clashes with the neoliberal policy of scientific work and research.

This does not mean, however, that academics blindly accepted this game, and in the name of output efficiency forgot the academic spirit. Academics are of course, aware of this technical pressure; they discuss it, they want to change the policy and develop resistance strategies for "the survival of the academic spirit".

Mountz et al. (2015) described in the following ten points the resistance strategies of slowing down. They claim that neoliberal universities need to stop, reflect, reject, resist, subvert, and collaborate to cultivate different, more reflexive academic cultures: (a) talk about and support slow strategies; (b) count what others do not; (c) organize (we need to engage at every level to accomplish a reconceptualization of university time); (d) take care (we must take care of ourselves before we can take care of others); (e) write fewer emails; (f) turn off email; (g) make time to think; (h) make time to write (differently); (i) say no, say yes; (j) reach for the minimum (rather than getting caught up in measuring worth by the number of peer-reviewed journal articles published or grant dollars procured).

The situation in the Czech Republic might not be as dramatic as portrayed in the scenario of the neoliberal University. For example, Czech universities are relatively remote from such depictions. This is illustrated by Jan Sokol, a professor of philosophy, who says: "We can do whatever we want at the

10 Types of authorship misconduct in scientific publications according to Bennett and Taylor (2003): gift authorship (inclusion, among the authors, of an individual who does not fulfil the requirements for authorship); pressured authorship (a person's use of his position of authority in order to be included as an author); ghost authorship (non-inclusion, among the authors, of individuals who played an effective part in the work); fragmentation (separate publication of various parts of the work, which could have been assembled into one publication); duplication (publication of the same paper in different journal).

11 See Beall (2015). 
university and we even get paid for that." (Fokus VM, 2016). Another major Czech philosopher and sociologist Václav Bělohradský also talks about the academic freedom in his work: "My whole life I was doing what I like doing and what I would have been doing even if I had not been paid for it. Thank God they didn't know that." (Fokus VM, 2016). Without perceiving the meaningfulness of one's own work, it would be possible to imagine the academic spirit only with much difficulty.

Last, but not least, Bourdie's (1988) division between academic power (in terms of the institution) and intellectual power should be mentioned. Those who might have academic power provided by strong anchoring in the institutional structure of the university might not possess intellectual power since they might not publish and lecture or their activity as such may not be accepted. On the other hand, an individual with a low position within the university structure or outside of it might have intellectual power, when their work receives acceptance. Bourdieu (1988) points out that for example, Althusser and Foucault held marginal positions in the university system.

\subsection{Academic spirit in the neoliberal curriculum}

Just as neoliberalism transforms science and research, it also transforms teaching at universities. We look at teaching through the university curriculum. Its transformation is mainly connected with new requirements for the content and outcome of education and with the massification of university education.

Massification of university education ${ }^{12}$, which is the increasing number of university students, is of course closely connected with the curriculum. Bourdieu (1988, p. 129) notes that "many authors only deal with the numerical effect of the transformation of universities." He adds that we cannot look only at the mechanical effects of overcrowded universities, such as the transformation of the community into a mass and of the academic into an educator." It is interesting to look directly into the classrooms. A large number of heterogeneous groups requires the transformation of teaching at universities and the transformation of the relationship between teachers and students. The importance of distance education has increased for example, through e-learning while seminar groups have grown larger or have been replaced by lectures. It's as if teaching was shifting into "standby mode".

12 Massification is also an effect of democratization. 
The transformation of higher education affects both academics and students. Let's now have a look at what it brings to students. Liessmann (2008) highlights Humboldt's precondition for entering university education, which was a real interest in science and its development. This, of course, narrows the circle of applicants. In the era of neoliberalism, such motivation for studying can be found rather sporadically. It is the students themselves who enter university with the requirement to be prepared for the labor market. The idea of complete detachment of the university from the labor market in the 21st century would not succeed even among the critics of neoliberalism.

However, it is clear that in the firmly professional-oriented education, the development of critical thinking proclaimed by critical-pedagogical movements is achieved only with difficulty. The university might thus resemble a production line that prepares a unified workforce via standardized procedures. It creates human capital while this term in the neoliberal discourse replaces expressions such as individual, citizen or worker (Štech, 2007). ${ }^{13}$

According to Štech (2007), human capital best describes the fact that capital accumulation today significantly depends on the innovation and transfer of knowledge, which in the Czech Republic is still a preserve of the primarily state-controlled schools and universities. In these, however, even such knowledge is passed on that from the perspective of the needs of the economy, which is comprised of businesses and entrepreneurs, is "redundant". This increases expenses and hence reduces the competitiveness of countries with such an "inefficient" public schooling system. Apple (2012, p. 6) comments ironically that neoliberalism as schools' salvation "will supposedly lead us to the promised land of efficient and effective schools".

From a critical-pedagogical perspective, general education is disputed in the name of effectiveness and may even be pushed away not only at primary and secondary schools, but also at universities. In teacher education, we can observe a weakening of general education (philosophy, sociology, natural science, cultural overview, etc.), and at the same time a strengthening of professional specialization. The pedagogical aspect is, however, conceived very narrowly, for example as practical-oriented methodology, instead of

13 The idea of schooling as an assembly line has been connected with primary and secondary education for a long time and pictured even in popculture (see Pink Floyd - Another Brick In The Wall), but was not visible in tertiary education before its massification. 
contemplating and questioning an issue. The result of such education is narrow specialization in a profession, which, however, does not in itself define a good teacher ${ }^{14}$. At first glance, the positive effect of education employment - has many perils. Professions, including pedagogical ones, change quite rapidly. In teaching, it is legislative framework changes; in the Czech Republic, a standard of a teacher emerges, new teaching methods appear, technology enters education, relationships between participants change and of course, knowledge also undergoes development. It might happen that universities will prepare students for the labor market of the past, instead of the labor market of the future.

University education focused on these trends might seem modern. Štech (2007, p. 328), however, points out that such a curriculum satisfies "the most utilitarian objectives - shaping a workforce which is flexible, promptly serviceable, loyal to the company, and sharing the goals and values of future employers." These goals are presented wrapped in words about autonomy and the responsibility of students, about their constant objective or "scientific" evaluation and self-evaluation and about the full development of the unique personality of each. The main objective is to convince everyone that they are actually not subjected to any violence because this is the only thinkable conception of modern education." This transformation of the university curriculum has only very little to do with the academic spirit and academic freedom. Students' general education and research appear to be something superfluous. The market does not require them and hence these characteristics of academic culture are pushed away from university education. Since students are not educated in the value and importance of academic freedom, academic freedom is weakened overall (Cowley in Aby \& Kuhn, 2000).

Academic freedom is important for all scientific disciplines. However, in the domain of teacher education, it can be attributed particular importance. The University environment provides a type of model for future teachers, which will be reflected in their future work with pupils. As mentioned by Dewey: academic freedom for teachers and students is essential for the creation of intelligence and the support of democracy. What is needed is free inquiry

14 For comparison, let us have a look at the concept of research-based teacher education, which introduces research into teacher education. It turns out that research-based teacher education develops not only their research competencies, but also professional and personal competencies (Aspfors \& Eklund, 2016). 
for students and teachers so they can see the value of intelligent action in the development of society (in Aby \& Kuhn, 2000). It is academic freedom that can help to facilitate the preparation of broadminded teachers. This means teachers with a wide theoretical background and cultural knowledge and research skills. Teachers who are able to think critically and who can lead their students to critical thinking. In the concept of critical pedagogy, these are teachers who turn the school into a democratic community. Giroux (2015a) emphasizes that "the very task of critical pedagogy is educating students to become critical agents who actively question and negotiate the relationships between theory and practice, critical analysis and common sense and learning and social change. Critical pedagogy opens up a space where students should be able to come to terms with their own power as critical agents". To achieve this, it is necessary that the university provides space for critical questioning by the students and lets them grow in a wider area than only the current form of the profession for which they are preparing.

However, neoliberal educational policies accent competencies as the output of educating, instead of the broadminded teacher mentioned above. The competency based movement can be traced further back to the 1920's in the United States, to ideas of educational reform linked to industrial/business models centered on specification of outcomes in behavioral objectives form. It is also important to mention the context of this transition - the clash of traditional with industrial era. ${ }^{15}$ From the mid-1960's onwards the demand for greater accountability in education, for increased emphasis of the economy gave a great impetus to the concept (Burke, 2005). The theoretical basis of this approach was experimentalism (see Burns \& Klingstedt, 1972) with the idea that the basis for preparing future teachers should be perceptible criteria of behavior. The doubt over whether a good teacher can be described by an inventory of competencies is often expressed. Korthagen $(2004$, s. 78) points out that "any attempt to describe the essential qualities of a good teacher should take into account that various levels are involved that fundamentally differ from each other. The level of teacher competencies is just one of these".

Štech (2007) points out that the very vague concept of competency comes from the realm of vocational (professional) education (cf. Burke, 2005). Its concepts and instruments should become the model of all education, from

15 Cf. industrial education by Dewey (Boydston, 1980). 
pre-school to university. He adds that the term is only seemingly neutral. It obscures the fact that the interconnection of theoretical knowledge and practice is very unclear. Competencies define the outcomes of education through the labor market. They are given from above ${ }^{16}$ and are an expression of the fact that the university prepares students for a particular profession. Critical pedagogues are mostly concerned that "central to the neoliberal view of higher education is market-driven paradigm that turn humanities into a job preparation service" (Giroux, 2015b, p. 182). The university hence becomes a training institution where the objectives and content of education is dictated by the labor market. Its role as a place of free research, production and reproduction of knowledge is weakened by this, as knowledge that cannot be cashed in on the labor market is not supported by neo-liberal policy.

The utilitarian concept of education as a basic postulate of educational neoliberalism has, according to Štech (2007, p. 330), two effects: (a) the first lies in the described efforts to adapt the university to life, or rather to the world of work; (b) under the pressure of the requirements of usefulness and adaptation of education, entire fields of culture, which are more difficult to exchange on the market, are gradually pushed away from education.

These effects limit the autonomy of the university, which might then start to resign from cultivating academic freedom and academic spirit.

\section{Conclusion: Critical Pedagogy as part of the academic spirit at university}

Neoliberalism can be seen in a similar manner as globalization - as a phenomenon widely criticized, but irreversible, at least by academics. Instead of a radical fight against neoliberalism at university, it seems to be a better approach to search for sustainable ways of academic life. This sustainability means, on one hand, the economic dimension (since academics are responsible for invested public resources) and on the other hand, cultivating academic freedom and not "selling" the academic spirit to the market. Academics hence balance an environment where there is a risk of slipping into one of these sides (to purely economically beneficial steps or

16 At present, all over the world, many attempts are being made to describe teachers' qualities by means of lists of competencies, something that seems to be strongly supported by policymakers. In contrast many researchers emphasize the more personal characteristics of teachers, such as enthusiasm, flexibility, or love of children (Korthagen, 2004). 
to boundless and irresponsible freedom). Searching for a balance between neoliberal elements at the university and academic freedom can be aided by critical pedagogy.

From the critical-pedagogical perspective, we can show how neoliberal policy in tertiary education limits academic freedom and thus academic spirit as well. What and how to research is specified by the market; academic work is tied by elements of materialism at universities. However, this does not mean that we have to play the game completely. We can develop research outside of grant schemes as grant schemes would not provide support since it contains non-traditional methodologies or focuses on topics that are marginal within education. Such research is likely to be slower and more frugal than research funded through large grant schemes. In spite of this, it can produce results that can, paradoxically, count and thereby contribute to the economic criterion of academic work. Focusing on the quality and meaningfulness of work is essential for the development of academic spirit. Texts that can be said not to count might be meaningful as well, if they are important for researchers, teachers or for the popularization of education. In this way, we leave the power discourse of science and enter the political discourse of practice, in which academics in the Czech Republic have a relatively weak word. But support from the practice can enhance the relevance of university as such.

In the management of a university, we can note that the university is a very specific (unique) institution and apply selected managerial tools very sensitively. We can balance managerialism out by strengthening the significance of the university community - again, by activities that can be said do not count - discussions, text readings, cooperation in research and teaching. This can be a practical form of critical pedagogy at the university, as it aims at what critical pedagogy calls for - to form democratic communities.

Critical pedagogy is also significant for students, in our case future teachers. When preparing teachers, we should definitely follow the requirements of the labor market, but this does not mean that it must become the determining factor for creating the curriculum. Our teaching should be informed in the area of current events, but free and independent of current labor market requirements. Free teaching is based particularly on one's own research (cf. Lojdová, 2016). Through research-based education, students can learn to interpret the macro-social context of education and develop their teacher identities as critical intellectuals (in contrast with competencies dictated 
by the education policy). How else to contribute to this than by educating future teachers in a community that possesses academic spirit and criticalpedagogical approaches to educational reality?

To conclude, the era of neoliberalism may not necessarily bring an end academic freedom. I would like to ask the reader to kindly forgive the provoking title. Provocation is one of the things that critical pedagogy is capable of. A certain degree of provocation can stimulate discussions, and hence has its place in social sciences.

\section{Acknowledgement}

I thank two anonymous reviewers. I also thank Radim Šíp and Jan Mareš from Masaryk University who gave me a lot of critical comments and new perspectives on an earlier version of the manuscript, although presented insights are my own and should not tarnish the reputations of these esteemed persons.

\section{References}

Aby, S. H., \& Kuhn, J. C. (2000). Academic freedom: A guide to the literature. Westport: Greenwood Publishing Group.

Apple, M. W. (2004). Ideology and curriculum. New York: Routledge.

Apple, M. W. (2006). Educating the "right" way: Markets, standards, God, and inequality. Abingdon: Taylor \& Francis.

Apple, M. W. (2012). Can education change society? New York: Routledge.

Apple, M. W. (2013). Education and power. New York: Routledge.

Aronowitz, S., \& Giroux, H. A. (2003). Education under siege: The conservative, liberal and radical debate over schooling. London: Routledge \& Kegan Paul.

Aspfors J., \& Eklund G. (2016, August). Newly qualified teachers' experiences of the research-based teacher education in Finland. Paper presented at the European Conference on Educational Research, Dublin.

Ball, S. J. (2012). Performativity, commodification and commitment: An I-spy guide to the neoliberal university. British Journal of Educational Studies, 60(1), 17-28.

Barnett, R. (2003). Beyond all reason: Living with ideology in the university. Buckingham: The Society for Research into Higher Education \& Open University Press.

Beall, J. (2015). Criteria for determining predatory open-access publishers. Retrieved from https:// scholarlyoa.files.wordpress.com/2015/01/criteria-2015.pdf (accessed 2015-02-14).

Bennett, D. M., \& Taylor, D. M. (2003). Unethical practices in authorship of scientific papers. Emergency Medicine, 15(3), 263-270. 
Bertrand, Y. (1998). Soudobé teorie vzdělávání. Praha: Portál.

Bourdieu, P. (1988). Homo academicus. Cambridge: Polity Press.

Boydston, J. A. (1980). The middle works of John Dewey, 1899-1924. Philosophy and Phenomenological Research, 40(3), 436-438.

Bränström Öhman, A. (2012). Leaks and leftovers: Reflections on the practice and politics of style in feminist academic writing. In M. Livholts (Ed.), Emergent writing methodologies in feminist studies (pp. 27-40). New York: Routledge.

Breunig, M. (2005). Turning experiential education and critical pedagogy theory into praxis. Journal of Experiential Education, 28(2), 106-122.

Burke, J. W. (Ed.). (2005). Competency based education and training. New York: Routledge.

Burns, R. W., \& Klingstedt, J. L. (Eds.). (1972). Competency-based education: An introduction. Englewood Cliffs: Educational Technology.

Collins, R. (2008). Conflict theory of educational stratification. In J. Spade \& J. Ballantine (Eds.), Schools and society: A sociological approach to education (pp. 35-44). Los Angeles: Pine Forge Press.

Darder, A., Baltodano, M., \& Torres, R. (2003). Critical pedagogy: An Introduciton. In A. Darder, M. Baltodano, \& R. Torres (Eds.), The critical pedagogy reader (pp. 1-21). New York: Routledge Falmer.

Darity, W. (Ed.). (2008). International Encyclopedia of the social science. Detroit: Macmillan Reference USA.

Dawson, M. (2013). Late modernity, individualization and socialism: An associational critique of neoliberalism. New York: Springer.

Dill, D. D. (1999). Academic accountability and university adaptation: The architecture of an academic learning organization. Higher education, 38(2), 127-154.

Farahmandpur, R. (2005). The revolutionary critical pedagogy of Peter McLaren. In M. Pruyn \& C. L. Huerta (Eds.), Teaching Peter McLaren: Paths of dissent (pp. 126-145). New York: P. Lang.

Fish, S. (2014). Versions of academic freedom: From professionalism to revolution. Chicago: University of Chicago Press.

Fokus VM (2016). Chudí a bohatí. Retrieved from http://www.ceskatelevize.cz/ porady/11054978064-fokus-vaclava-moravce/215411030530004/

Foucault, M. (1975). Discipline and punish: The birth of the prison. New York: Random House.

Freire, P. (2000). Pedagogy of the oppressed. New York: Continuum.

Giroux, H. A. (2001). Vocationalizing higher education: Schooling and the politics of corporate culture. In H. A. Giroux \& K. Myrsiades (Eds.), Beyond the corporate university: Culture and pedagogy in the new millennium (pp. 29-44). Lanham: Rowman \& Littlefield.

Giroux, H. A. (2004). The terror of neoliberalism: Authoritarianism and the eclipse of democracy. Herndon: Paradigm Publishers.

Giroux, H. (2012a). Neoliberal politics as failed sociality: Youth and the crisis of higher education. Logos, 11(4).

Giroux, H. A. (2012b). Neoliberar terror and the age of disposability. Retrieved from http:// logosjournal.com/2011/neoliberal-politics-as-failed-sociality-youth-and-the-crisisofhigher-education/ 
Giroux, H. A. (2013). Public intellectuals against the neoliberal university. Qualitative inquiry outside the academy, $9(35)$.

Giroux, H. A. (2015a). University in chains: Confronting the military-industrial-academic complex. New York: Routledge.

Giroux, H. A. (2015b). America's addiction to terrorism. New York: NYU Press.

Greger, D., Simonová, J., \& Straková, J. (2015). Spravedlivý start? Nerovné šance v předškolním vzdělávání a při precechodu na základní školu. Praha: Univerzita Karlova v Praze, Pedagogická fakulta.

Guthrie, E. (Ed.). (2003). Encyclopedia of education. New York: Macmillan Reference USA.

Hadley, G. (2015). English for academic purposes in Neoliberal Universities: A critical grounded theory. Cham: Springer International Publishing.

Harrington, A. (Ed.). (2006). Moderní sociální teorie: základní témata a myšlenkové proudy. Praha: Portál.

Harris, S. (2005). Rethinking academic identities in neo-liberal times. Teaching in higher Education, 10(4), 421-433.

Hohendahl, P. U. (2011). Humboldt revisited: Liberal education, university reform, and the opposition to the neoliberal university. New German Critique, 38(2), 159-196.

Horn, M. (1999). Academic freedom in Canada: A history. Toronto: University of Toronto Press.

Cho, S. (2010). Politics of critical pedagogy and new social movements. Educational Philosophy \& Theory, 42(3), 310-325.

Cho, S. (2012) Critical pedagogy and social change: Critical analysis on the language of possibility. New York: Routledge.

Illich, I. (2001). Odškolnění společnosti: polemický spis. Praha: Sociologické nakladatelství.

Kaščák, O., \& Pupala, B. (2011). Neoliberalizmus vo vzdelávaní: pät' obrazov kritických analýz. Pedagogická orientace, 21(1), 5-34.

Keller, J. (2012). Úvod do sociologie. Praha: Sociologické nakladatelství.

Kennedy, D. (1997). Academic duty. Cambridge: Harvard University Press.

Kincheloe, J. L. (2004a). Introduction. In J. Kincheloe \& S. Steinberg (Eds.), The miseducation of the West: How schools and the media distort our understanding of the Islamic world (p. 1-6) Westport: Praeger.

Kincheloe, J. (2004b). Critical pedagogy primer. New York: P. Lang.

Kincheloe, J. (2007). Critical Pedagogy in the twenty-first century. In P. McLaren \& J. L. Kincheloe (Eds.), Critical pedagogy: Where are we now? (pp. 9-42). New York: Peter Lang.

Korthagen, F. A. (2004). In search of the essence of a good teacher: Towards a more holistic approach in teacher education. Teaching and Teacher Education, 20(1), 77-97.

Liessmann, K. P. (2008). Teorie nevzdělanosti: omyly společnosti vědění. Praha: Academia.

Lojdová, K. (2016). Sňatek z rozumu? Výzkum a výuka v pregraduální přípravě učitelů na př́íkladu kvalitativního výzkumu. Pedagogická orientace, 26(1), 51-75.

Lupták, L. (2013). Neoliberalismus a marginalita: studie z českého reálkapitalismu. Brno: Doplněk.

Lynch, K. (2006). Neo-liberalism and marketisation: The implications for higher education. European Educational Research Journal, 5(1), 1-17.

McLaren, P. (1998). Life in schools. Reading: Longman. 
McLaren, P. (1999). Schooling as a ritual performance: Toward a political economy of educational symbols and gestures. Lanham: Rowman \& Littlefield Publishers.

Hatcher, C., Meadmore, D., \& McWilliam, E. (1999). Developing professional identities: Remaking the academic for corporate times. Pedagogy, Culture and Society, 7(1), 55-72.

Mountz, A., Bonds, A., Mansfield, B., Loyd, J., Hyndman, J., Walton-Roberts, M., \& Curran, W. (2015). For slow scholarship: A feminist politics of resistance through collective action in the neoliberal university. ACME: An international E-journal for Critical Geographies, 14(4), 1235-1259.

Orelus, P. (2011). When theory walks with praxis: Critical pedagogy and the life of transnational and postcolonial subjects of colour. In C. Malott \& B. J. Porfilio (Eds.), Critical pedagogy in the twenty-first century: A new generation of scholars (pp. 3-22). Charlotte: Information Age Pub.

Pavlík, M., \& Bělčík, M., et al. (2010). Společenská odpovědnost organizace: CSR v praxi a jak s ním dál. Praha: Grada.

Peters, M. A. (2013). Managerialism and the neoliberal university: Prospects for new forms of "open management" in higher education. Contemporary Readings in Law and Social Justice, 5(1), 11-26.

Semali, L. (1998). Still crazy after all of these years: Teaching critical media literacy. In S. Steinberg (Ed.), Unauthorized methods: Strategies for critical teaching (pp. 137-151). New York: Routledge.

Strathern, M. (Ed.). (2000). Audit cultures: Anthropological studies in accountability, ethics, and the academy. London: Routledge.

Smith, M., \& McLaren, P. (2010). Critical pedagogy: An overview. Childhood Education, 86(5), 332-334.

Steinberg, S. (2007). Where are we now. In P. McLaren \& J. L. Kincheloe (Eds.), Critical pedagogy: Where are we now? (pp. 9-10). New York: Peter Lang.

Šima, K., \& Pabian, P. (2013). Ztracený Humboldtův ráj: ideologie jednoty výzkumu a výuky ve vysokém školství. Praha: Sociologické nakladatelství.

Štech, S. (2007). Profesionalita učitele v neo-liberální době: esej o paradoxní situaci učitelství. Pedagogika, 57(4), 326-337.

Torres, C. A. (2008). Education and neoliberal globalization. New York: Routledge.

Weber, M. (2002). The protestant ethic and the spirit of capitalism and other writings. London: Routledge.

\section{Author}

Mgr. Kateřina Lojdová, Ph.D., Masaryk University, Faculty of Education, Department of Education, Pořrićí 31, 60300 Brno, Czech Republic, e-mail: lojdova@ped.muni.cz 


\section{Konec akademické svobody $\mathrm{v}$ éře neoliberalismu?}

Abstrakt: Tento článek diskutuje možné konsekvence neoliberalismu pro současné university. Zaměřuje se $\mathrm{v}$ perspektivě kritické pedagogiky na možné konflikty neoliberalismu s akademickou svobodou jakožto hlavní součástí akademického ducha na univerzitách. Článek je rozdělen do dvou částí. První část přibližuje kritickou pedagogiku, její kořeny a současnou podobu, včetně limitů, které tento koncept má. Druhá část se již v kriticko-pedagogickém pohledu věnuje neoliberální proměně výzkumu a výuky na univerzitách na př́kladu pedagogických fakult. Závěr nastiňuje možnosti kritické pedagogiky k pěstování akademického ducha na univerzitách. Shledává je např́íklad ve výzkumu nezávislém na grantových schématech, avšak relevantních pro odbornou komunitu, $\mathrm{v}$ citlivém managementu univerzit a v kurikulu pregraduální přípravy učitelů akcentujícím spíše svobodného učitele nežli kompetenční orientaci vzdělávání diktovanou shora. Článek tak ústí do smírlivé vize udržitelného akademického života, která balancuje na pomezí mezi ekonomickou dimenzí univerzit na straně jedné a akademickou svobodou nezávislou na trhu práce na straně druhé.

Klíčová slova: akademická svoboda, kompetenčně orientované vzdělávání, kritická pedagogika, kritická teorie, neoliberalismus, pregraduální vzdělávání učitelů, terciární vzdělávání 